\title{
REDUPLIKASI DAN KATA MAJEMUK DALAM BAHASA MANGGARAI DIALEK KOLANG DI KABUPATEN MANGGARAI BARAT
}

Oleh Hendrikus Jehane, M. Hum.

e-mail: hendrikjehane@gmail.com

FKIP Universitas Nusa Cendana

\begin{abstract}
ABSTRAK
Bahasa Manggarai dialek Kolang (BMDK) merupakan salah satu dialek yang termasuk dalam kelompok dialek (KD) Manggarai S > H (Verheijen, 1930). Kelompok dialek S > H masih belum dikenal luas oleh masyarakat Manggarai pada umumnya dan oleh para peneliti khususnya. Berbeda dengan KD Manggarai Tengah yang dikenal dan dipahami oleh sebagian besar masyarakat Manggarai karena fungsi dan peranannya sebagai bahasa Manggarai standar. Oleh karena itu KD Manggarai $\mathrm{S}>\mathrm{H}$ perlu diteliti dan diperkenalkan melalui artikel ilmiah agar dikenal lebih luas. Masalah penelitian ini adalah: (1) Bagaimanakah bentuk dan makna reduplikasi dalam BMDK?; (2) Bagaimanakah bentuk dan makna kata majemuk dalam BMDK?. Tujuan penelitian ini adalah: (1) untuk memerikan bentuk dan makna reduplikasi dalam BMDK; (2) untuk memerikan bentuk dan makna kata majemuk dalam BMDK. Metode penelitian yang digunakan dalam penelitian ini adalah metode deskriptif, karena data yang dibutuhkan adalah data bahasa yang digunakan oleh masyarakat penuturnya dalam komunikasi sehari antarpenuturnya.

Hasil penelitian sebagai berikut. (1) Bentuk reduplikasi BMDK terdiri atas dua tipe utama, yaitu: (1) tipe I adalah reduplikasi tanpa perubahan fonem vokal dan (2) dan tipe II adalah reduplikasi dengan perubahan fonem vokal. Makna reduplikasi terdiri atas lima macam yaitu: (1) menyatakan intensif (sungguh-sungguh); (2) menyatakan makna iteratif (berkali-kali); (3) menyatakan makna kelompok; (4) menyatakan makna deintensif (kurang sungguh-sungguh); (5) menyatakan makna jamak; dan (6) menyatakan makna melebihkan. Kata majemuk dalam BMDK terdiri atas dua jenis, yaitu kata majemuk koordinatif dan kata majemuk subordinatif. Kata majemuk koordinatif dalam BMDK kurang produktif jika dibandingkan dengan kata majemuk subordinatif. Kata majemuk koordinatif hanya ditemukan satu tipe yakni berkategori nomina dan konstituennya terdiri atas nomina $(N+N=N)$. Kata majemuk subordinatif lebih produktif, terdiri atas tujuh tipe.
\end{abstract}

Kata kunci: reduplikasi, kata majemuk, dialek Kolang, kelompok dialek $S>H$, bentuk, makna.

\section{ABSTRACT}

The Manggarai language, Kolang dialect is one of the dialects included in the Manggarai $S>H$ dialect group (Verheijen, 1930). The $\mathrm{S}>\mathrm{H}$ dialect group is still not widely known by the Manggarai community in general and by researchers in particular. It is different from Central Manggarai dialect group which is known and understood by most Manggarai people because of its function and role as the standard Manggarai language. Therefore, Manggarai $S>H$ dialect group needs to be researched and introduced through scientific articles to make it more widely known. The research problems are: (1) What is the form and meaning of reduplication in the Manggarai language, Kolang dialect ?; (2) What is the form and meaning of the compound word in the Manggarai language, Kolang dialect? The objectives of this study were: (1) to describe the form and meaning of reduplication in the Manggarai language, Kolang dialect; (2) to describe the form and meaning of the compound word in the Manggarai language, Kolang dialect. The research method used in this research is descriptive method, because the data needed is the language data used by the speaking community in day-today communication between speakers. 
The research results are as follows. (1) The form of the Manggarai language, Kolang dialect reduplication consists of two main types, namely: (1) type I is reduplication without changes in phonemes and (2) and type II is reduplication with changes in phonemes. The meaning of reduplication consists of five types, namely: (1) to state intensive (really); (2) states an iterative meaning (many times); (3) states the meaning of the group; (4) states the meaning of deintensive (not really); (5) states the plural meaning; and (6) states the meaning of exaggeration. The compound word in the Manggarai language, Kolang dialect consists of two types, namely coordinative compound words and subordinative compound words. Coordinative compound words in the Manggarai language, Kolang dialect are less productive when compared to subordinative compounds. There is only one type of coordinative compound words, namely the category of nouns and the constituents consist of nouns $(N+N=N)$. Subordinative compound words are more productive, consisting of seven types.

Keywords: reduplication, composition, Kolang dialect, dialect group $S>H$, form, meaning

\section{PENDAHULUAN \\ 1.1 Latar Belakang Permasalahan}

Bahasa Manggarai adalah bahasa yang dituturkan oleh masyarakat yang mendiami wilayah Manggarai raya. Wilayah Manggarai raya dewasa ini terbagi atas tiga kabupaten, yaitu Kabupaten Manggarai, Kabupaten Manggarai Barat, dan Kabupaten Manggarai Timur. Semula sejak Indonesia merdeka, wilayah Manggarai raya hanya terdiri atas satu kabupaten yaitu Kabupaten Manggarai. Pada tahun 2003 Kabupaten Manggarai dimekarkan menjadi dua kabupaten, yaitu Kabupaen Manggarai dan Kabupaten Manggarai Barat. Kabupaten Manggarai Barat dibentuk berdasarkan Undang-undang no. 8 tahun 2003. Selanjutnya tahun 2007 Kabupaten Manggarai dimekarkan lagi menjadi dua kabupaten, yaitu Kabupaten Manggarai dan Kabupoaten Manggarai Timur. Kabupaten Manggarai Timur dibentuk berdasarkan Undang-Undang no. 36 tahun 2007. Walaupun Manggarai raya telah terbagi menjadi tiga kabupaten, bahasa dan budaya Manggarai tidak berubah.

Menurut peta bahasa dan budaya Manggarai raya yang dibuat oleh Verheijen (1930) dalam bukunya "Manggarai dan Wujud Tertinggi" yang diterbitkan tahun 1991, bahasa Manggarai dibagi atas lima kelompok dialek (KD), yakni (1) KD Manggarai Timur Jauh, (2) KD Manggarai Timur, (3) KD Manggarai Tengah, (4) KD Manggarai S>H, dan (5) KD Manggarai Barat. Kelompok dialek tersebut terbagi lagi atas beberapa dialek. Menurut peta bahasa tersebut dialek Kolang termasuk dalam KD Manggarai S $>\mathrm{H}$ bersama Berit (Bari), Regho, Nggalak, Pacar, Ndoso (sebagian), Lelak (sebagian), Welak, dan Munting. Menurut pengamatan penulis, peta yang dibuat Verheijen pada tahun 1930 ini masih relevan dengan situasi kebahasaan Manggarai dewasa ini.

Perlu dijelaskan pula di sini mengapa kelompok dialek yang terletak antara KD Manggarai Tengah dengan KD Manggarai Barat ini disebut KD manggarai $\mathrm{S}>\mathrm{H}$. Pengelompokan ini berdasarkan kecenderungan fonologis. Rumusan $\mathrm{S}>\mathrm{H}$ dibaca "S menjadi $H^{\prime \prime}$. Maksudnya, fonem /s/ dalam KD Manggarai Barat dan Tengah menjadi /h/ dalam KD 
Manggarai S>H. Misalnya, salang 'jalan' dalam KD Manggarai Tengah dan Barat menjadi halang 'jalan' dalam KD Manggarai S>H. Demikian juga molas 'cantik', lasa 'sakit' menjadi molah 'cantik, laha 'sakit' dalam KD dialek $\mathrm{S}>\mathrm{H}$.

Perbedaan antara KD Manggarai lain dengan KD Manggarai $\mathrm{S}>\mathrm{H}$ tidak hanya pada tataran fonologis tetapi juga terjadi pada tataran leksikal maupun gramatikal. Perbedaan dalam tataran leksikal, misalnya kata ende 'ibu', ema 'ayah', meu 'kamu' dalam KD Manggarai Tengah, dalam dialek kolang disebut ine 'ibu', ame 'ayah', ghemi 'kamu'. Perbedaan dalam tataran gramatikal, misalnya:

KD Manggarai Tengah: Kole le mai uma-km

Pulang PREPLOK kebun KLT

'kami pulang dari kebun'

KD Manggarai S > H: Kole le mai umaghami

Pulang PREPLOK kebun 3J

'kami pulang dari kebun'

Contoh di atas menunjukkan bahwa aktor kami ' $3 \mathrm{~J}$ ' dalam kalimat pertama (KD Manggarai Tengah) diklitikkan menjadi - $k m$ dilekatkan pada lokatif uma 'kebun', sedangkan dalam kalimat kedua (KD Manggarai S > H) aktor ghami '3J' tidak diklitikkan.

Hasil studi pustaka menunjukkan bahwa penelitian mengenai struktur morfemis bahasa Manggarai dialek Kolang (Selanjutnya disebut BMDK), khususnya reduplikasi dan kata majemuk, belum pernah diteliti oleh peneliti sebelumnya. Penelitian yang dilakukan oleh peneliti sebelumnya sebagaian besar KD Manggarai Tengah dan KD Manggarai Barat. Berybe (1982) meneliti tentang pembentukan verba dan nomina dalam KD Manggarai Tengah; Troeboes dkk. (1984/1985) meneliti struktur bahasa Manggarai (KD Manggarai Tengah,); Semiun, dkk. (1993) meneliti tentang struktur Gramatika Bahasa Manggarai Dialek Kempo (KD Manggarai Barat); Semiun, dkk. (1995) meneliti Nominalisasi Verba Bahasa Manggarai (KD Manggarai Barat); Jeladu (1995) meneliti Kata Tugas Bahasa Manggarai Dialek Regho (KD Manggarai S > H), Jeladu (1998) meneliti tentang Pemetaan Argumen Aktor dalam Bahasa Manggarai KD Manggarai Tengah; Gande (2001) meneliti Reduplikasi Morfemis Bahasa Manggarai dialek Kempo. Dari sejumlah penelitian yang telah dilakukan di atas penelitian tentang reduplikasi dan kata majemuk dalam BMDK belum pernah dilakukan. Dengan demikian, gambaran mengenai reduplikasi dan kata majemuk dalam bahasa Manggarai subdialek Kolang belum diketahui secara pasti, oleh sebab itu perlu dilakukan suatu penelitian ilmiah.

Peneliti memutuskan untuk meneliti reduplikasi dan kata majemuk BMDK dilandasi beberapa pertimbangan.

(1) Penelitian bahasa Manggarai yang telah dirintis oleh para peneliti terdahulu perlu dikembangkan atau dilanjutkan dengan penelitian yang mencakup semua kelompok dialek bahasa Manggarai agar mendapat gambaran yang utuh mengenai struktur bahasa Manggarai secara keseluruhan. 
(2) Hasil penelitian mengenai struktur BMDK dapat menjadi salah satu acuan dalam menyusun bahan pembelajaran bahasa Manggarai di sekolah jika tiba saatnya nanti bahasa Manggarai masuk dalam kurikulum pendidikan di wilayah Manggarai Raya.

(3) Hasil penelitian reduplikasi dan kata majemuk dalam BMDK dapat memberikan sumbangan bagi kajian kontrastif dalam rangka meningkatkan pembelajaran bahasa Indonesia bagi siswa sekolah dasar di wilayah itu.

(4) BMDK merupakan salah satu khasanah budaya daerah yang perlu dikaji dan dilestarikan.

\subsection{Rumusan Masalah}

Berdasarkan latar belakang yang dipaparkan di atas, masalah yang akan dikaji dalam penelitian ini adalah: (1) Bagaimanakah bentuk dan makna reduplikasi dalam BMDK?; (2) Bagaimanakah bentuk dan makna kata majemuk dalam BMDK?

\subsection{Tujuan Penelitian}

Tujuan penelitian ini adalah: (1) untuk memerikan bentuk dan makna reduplikasi dalam BMDK; (2) untuk memerikan bentuk dan makna kata majemuk dalam BMDK.

\subsection{Manfaat Penelitian}

Penelitian ini bermanfaat bagi pengembangan ilmu pengetahuan, yakni pengembangan linguistik atau ilmu bahasa. Selain itu, penelitian ini bermanfaat pula bagi pelestarian bahasa Manggarai sebagai salah satu khasanah budaya daerah. Manfaat lainnya, hasil penelitian ini dapat memberi sumbangan bagi bahan pembelajaran bahasa daerah jika tiba saatnya nanti bahasa daerah Manggarai di ajarkan di sekolah sebagai salah satu mata pelajaran muatan lokal.

\section{TINJAUAN PUSTAKA}

Redupikasi dan kata majemuk merupakan kata turunan yang merupakan transformasi dari leksem atau kata dasar. Kata turunan seperti reduplikasi dan kata majemuk terbentuk melalui proses morfologis atau proses pembentukan kata.

Ada beberapa pandangan mengenai proses pembentukan kata, yang tercermin dalam polemik tentang hakikat pembentukan kata yang memunculkan pertanyaan pokok tentang dasar pembentukan kata, apakah morfem, kata, atau leksem. Pandangan pertama menyatakan bahwa dasar pembentukan kata adalah morfem. Pandangan ini antara lain tampak dalam definisi Nida (1949) yang menyatakan bahwa morfologi adalah studi tentang morfem-morfem dan bagaimana pengaturannya dalam rangka pembentukan kata. Berkaitan dengan itu Hockett (1958) menyatakan bahwa morfem adalah elemen terkecil dan bermakna dalam ujaran. Halle (1975) dalam artikelnya yang berjudul "Proglomena to a Theory of Word Formation" juga secara tegas menyatakan bahwa unit dasar sebuah leksikon adalah morfem. Morfem-morfem itu (list of 
morphems) merupakan in put bersama membentuk kata melalui kaidah pembentukan kata (word formation rules). Kemudian hasil pembentukan kata itu disaring (filter) untuk menahan semua bentuk yang tidak berterima. Bentuk kata yang lolos dari saringan masuk dalam kamus (dictionary of words).

Pandangan kedua menyatakan bahwa dasar pembentukan kata adalah kata. Aronoff (1978) menyatakan bahwa kata merupakan tanda (sign) terkecil dalam morfologi. la menolak hipotesis morfem sebagai dasar pembentukan kata karena morfem tidak memiliki makna yang tetap dan dalam kasus tertentu morfem itu tidak memiliki makna sama sekali. Kaidah pembentukan kata (word formation rules) adalah kaidah yang beraturan, hanya akan menurunkan sesuatu yang bermakna dari dasar yang bermakna. Oleh karena itu, hanya kata yang dapat menjadi dasar pembentukan kata. Aronoff mengajukan hipotesis sebagai berikut, (1) dasar pembentukan kata adalah kata, (2) kata tersebut adalah kata yang benar-benar kata ( tidak termasuk kata yang potensial), (3) kaidah pembentukan kata berlaku untuk kata tunggal, bukan frasa dan bukan bentuk terikat, (4) baik in put maupun out put pembentukan harus merupakan anggota dari kategori leksikal yang utama.

Kedua pandangan di atas bukannya tanpa kelemahan. Keberatan yang timbul dari pandangan Halle yang menyatakan morfem sebagai dasar pembentukan kata adalah adanya afiks derivasional dan infleksional yang termasuk dalam daftar morfem.

Seharusnya afiks hanya muncul dalam kaidah pembentukan kata. Afiks tidak dapat diperlakukan sama dengan kata (lexical morphems) sehingga tidak dapat menjadi dasar pembentukan kata. Keberatan terhadap Aronoff (1973) adalah bahwa word based hypothesis tidak dapat mengakomodasi kata yang terbentuk dari frasa seperti kata "ketidaktahuan" dalam bahasa Indonesia yang berbentuk dasar frasa "tidak tahu", bukan "tidak" atau "tahu". Jika hipotesis Aronoff diterapkan pada pembentukan kata "ketidaktahuan", maka prosesnya adalah " tidak + tahu + ke-an". Penutur bahasa Indonesia tidak dapat mnenerima proses seperti itu. Kesulitan lain adalah bagaimana menjelaskan kata yang terbentuk dari akronim seperti "dimahmilubkan".

Alternatif lain adalah model yang dikembangkan oleh Kridalaksana (1992) dalam bukunya yang berjudul "Pembentukan Kata dalam Bahasa Indonesia". Hal yang paling mendasar dalam model ini adalah pemanfaatan konsep leksem sebagai tanda bahasa. Menurut Kridalaksana, kata merupakan satuan yang terbesar dari morfologi dan sekaligus sebagai satuan terkecil dari sintaksis. Hal ini jelas bertentangan dengan pandangan Aronoff (1973) yang menganggap kata sebagai satuan yang terkecil dari sintaksis maupun morfologi. Jadi menurut Kridalaksana unit terkecil dalam leksikon adalah leksem, bukan kata atau morfem. Dengan demikian, leksemlah yang menjadi dasar pembentukan kata.

Dengan kata lain, leksem sebagai satuan leksikal berperan sebagai in put dalam proses morfologis, sedangkan kata sebagai in put sintaksis. Leksem itu merupakan: (1) 
unit terkecil dalam leksikon, (2) satuan yang berperan sebagai in put dalam proses morfologis, (3) bahan baku dalam proses morfologis, (4) unsur yang diketahui adanya dari bentuk yang setelah disegmentasi dari bentuk kompleks merupakan bentuk dasar yang lepas dari proses morfologis, (5) bentuk yang tidak tergolong proleksem atau partikel. Model yang dikembangkan oleh Kridalaksana inilah yang digunakan peneliti dalam mengkaji proses pembentukan kata atau proses morfologis bahasa Manggarai Dialek Kolang di Kabupaten Manggarai Barat. Proses itu dijelaskan dalam bentuk bagan sebagai berikut.

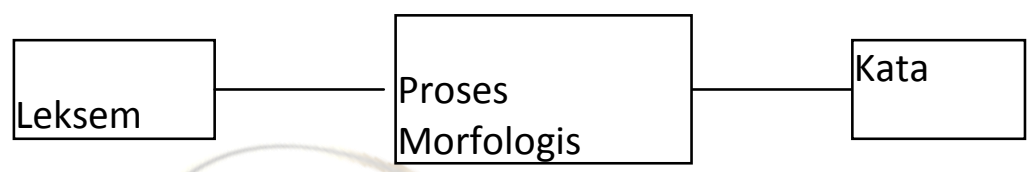

\section{Bagan Proses Morfologis (sumber Kridalaksana 1992:12)}

Pembentukan kata atau proses morfologis itu terdiri atas derivasi zero, afiksasi, reduplikasi, abreviasi, kata majemuk dan derivasi balik .1) derivasi zero: perubahan leksem menjadi kata tunggal tanpa perubahan; 2) afiksasi : perubahan leksem menjadi kata kompleks; 3) reduplikasi : perubahan leksem menjadi kata kompleks dengan beberapa cara proses pengulangan ; 4) abreviasi (pemendekan): perubahan leksem menjadi gabungan beberapa leksem menjadi kata kompleks atau akronim atau singkatan; 5) kata majemuk (perpaduan): dalam proses ini dua leksem atau lebih berpadu dan output-nya adalah paduan leksem. Atau kompositum pada tingkat morfologi atau kata majemuk pada tingkat sintaksis.

\section{METODE PENELITIAN}

\subsection{Metode}

Metode yang digunakan dalam penelitian ini adalah metode deskriptif yang berarti mencatat atau merekam aspek reduplikasi dan kata majemuk dalam BMDK sesuai yang dipakai oleh penuturnya sehari-hari.

\subsection{Lokasi Penelitian}

Data reduplikasi dan kata majemuk dalam BMDK diperoleh dari penelitian lapangan yang dilakukan di Golo Pua Kecamatan Kuwus Kabupaten Manggarai Barat. Selain itu, data juga diperoleh dari hasil kajian cerita rakyat dalam BMDK baik yang dituturkan oleh pemakai bahasa tersebut maupun dari teks-teks yang sudah ada.

\subsection{Teknik Pengumpulan Data}

Data penelitian dikumpulkan dengan teknik-teknik sebagai berikut:

1) rekaman bahasa lisan yang terjadi dalam berbagai konteks situasi

2) observasi bahasa lisan yang terjadi dalam berbagai konteks situasi

3) partisipasi untuk mengecek diterima atau tidaknya kata yang digunakan peneliti

4) kajian teks 
5) wawancara untuk mengecek berterima tidaknya satu bentuk tertentu dalam bahasa itu

6) pancingan dengan terjemahan

\subsection{Teknik Analisis Data}

Data yang telah diperoleh dianalisis dengan cara sebagai berikut:

1) menganalisis teks sampai bentuk yang terkecil yaitu leksem

2) menguji proses morfologis dengan leksem yang tersedia

3) menguji keberterimaan bentuk itu dengan data yang lain yang diperoleh dengan teknik yang lain.

\section{HASIL PENELITIAN DAN PEMBAHASAN}

\subsection{Reduplikasi}

\subsubsection{Bentuk Reduplikasi}

Data yang terkumpul menunjukkan bahwa reduplikasi BMDK memiliki bentuk yang unik dan beragam. Setelah dikaji secara cermat, bentuk yang paling menonjol dari keragaman bentuk reduplikasi itu terletak pada ada atau tidak adanya perubahan fonem. Dengan demikian reduplikasi BMDK dibedakan atas dua tipe utama, yaitu (1) reduplikasi tanpa perubahan fonem dan (2) reduplikasi dengan perubahan fonem. Bentuk reduplikasi yang lain dianggap sebagai varian dari kedua tipe tersebut. Dengan demikian pembahasan reduplikasi BMDK tidak mengikuti model konvensional yang membedakan reduplikasi atas (1) reduplikasi penuh atau total, (2) reduplikasi sebagian atau parsial, dan (3) reduplikasi berubah bunyi.

1) Reduplikasi Tanpa Perubahan Fonem Vokal (Tipe I)

Tipe I ini memiliki tiga varian.

Varian I: jika masukannya berupa leksem yang berakhir dengan fonem vokal maka luarannya (reduplikasinya) tidak mengalami perubahan bentuk.

Varian II: jika masukannya berupa leksem yang berakhir dengan fonem konsonan maka konsonan akhir pada konstituen reduplikasi sebelah kanan mengalami pelesapan.

Varian III: jika masukannya terdiri atas tiga silabi walaupun diakhiri konsonan, konsonan tersebut tidak mengalami pelesapan.

Contoh:

Varian I:

leksem

lako 'jalan'

gula 'pagi'

penso 'menghentakkan kaki'

kole 'pulang'

lelo 'lihat'

hua 'dua'

$\begin{array}{ll}\text { reduplikasi } & \\ \text { lako-lako } & \text { 'jalan-jalan' } \\ \text { gula-gula } & \text { 'pagi-pagi' } \\ \text { penso-penso } & \text { 'menghentak-hentakkan kaki' } \\ \text { kole-kole } & \text { 'pulang kembali' } \\ \text { lelo-lelo } & \text { 'melihat-lihat' } \\ \text { hua-hua } & \text { 'dua-dua' }\end{array}$

http://ejurnal-pendidikanbahasaundana.com - 18 


$\begin{array}{ll}\begin{array}{l}\text { Varian II: } \\ \text { leksem }\end{array} & \\ \text { hekang } & \text { 'rumah' । } \\ \text { lewing } & \text { 'periuk' } \\ \text { labar } & \text { 'bermain' } \\ \text { witek } & \text { 'melucu' } \\ \text { rentot } & \text { 'berhenti sejenak' }\end{array}$

reduplikasi

heka-hekang 'rumah-rumah'

lewi-lewing 'periuk-periuk'

laba-labar 'bermain-main'

wite-witek 'melucu-lucu'

rento-rentot 'kadang turun/jalan kadang berhenti'

Varian III:

leksem

$\begin{array}{ll}\text { kerkotek } & \text { 'seperti bunyi kuku kuda yang berjalan di bebatuan' } \\ \text { nggernggatang } & \text { 'seperti bunyi roda di atas jalan bebatuan' } \\ \text { perpekat } & \text { 'cara jalan seperti anak yang baru belajar berjalan' } \\ \text { mbermbikah } & \text { 'seperti air yang keluar/muncrat ke segala arah' } \\ \text { perpotat } & \text { 'tumbuh/ keluar hanya satusatu' } \\ \text { reduplikasi } & \end{array}$

kerkotek-kerkotek 'menyatakan intensitas bunyi kerkotek' nggernggatang-nggerngggatang'menyatakan intensitas bunyi nggernggatang' perpekat-perpekat 'menyatakan intensitas cara jalan yang tidak teratur' mbermbikah-mbermbikah 'menyatakan intensitas muncrat yang tak teratur' perpotat-perpotat 'menyatakan kejarangan keluar/tumbuhnya sesuatu' 2) Reduplikasi dengan Perubahan Fonem Vokal (Tipe II)

Tipe ini memiliki dua varian.

Varian I: semua fonem vokal pada silabi pertama dalam bentuk dasar berubah menjadi /a/ dalam duplikatnya. Bentuk dasar di sebelah kiri, duplikat di sebelah kanan. Jika leksem dasarnya berakhir dengan fonem konsonan, maka fonem tersebut dilesapkan. Pelesapan terjadi pada bentuk dasar, bukan pada duplikat.

Contoh (1) Jika leksem dasarnya berakhir dengan fonem vokal

\begin{tabular}{lll}
\multicolumn{2}{l}{ leksem } & \multicolumn{2}{l}{ reduplikasi } & \\
\cline { 3 - 3 } lelo 'lihat' & lelo-lalo & 'melihat ke kiri dan ke kanan' \\
pote 'pilin' & pote-pate & 'putar balik' \\
wuli 'bergerak' & wuli-wali & 'bergerak merontak' \\
ghuli 'bergerak' & ghuli-ghali & 'bergerak-gerak'
\end{tabular}

Contoh (2) Jika leksem dasarnya berakhir dengan fonem konsonan

leksem

gholeh 'membalikkan badan'

ropeh 'badan kotor'

nggopet 'mencopet' reduplikasi

ghole-ghaleh 'membolak balikkan

$$
\text { badan' }
$$

rope-rapeh 'badan kotor sekali'

nggope-nggapet 'suka mencuri' 
mbekot 'bengkok'

riput 'keriting'

wekok 'mengibaskan ekor' mbeko-mbakot 'berbengko-bengkok

ripu-raput 'keriting tak terurus'

weko-wakok 'mengibas-ibaskan ekor'

Ada juga bentuk seperti ini tetapi tidak dikenali bentuk dasarnya. Namun, diduga pada masa lampau salah satu unsurnya merupakan leksem. Beranalogi pada bentuk di atas, diduga leksem dasar bentuk reduplikasi di bawah ini adalah luit, lopet, dan jobe.

Contoh :

$\frac{\text { leksem }}{?}$
$?$
$?$

$\begin{array}{ll}\frac{\text { reduplikasi }}{\text { lui-lait }} & \text { 'omong kosong' } \\ \text { lope-lapet } & \text { 'berbual' } \\ \text { jobe-jabe } & \text { 'bicara banyak' }\end{array}$

Varian II: Semua fonem vokal, baik vokal pada suku pertama maupun pada suku kedua berubah menjadi /a/ dan /i/ dalam duplikatnya. Bentuk dasar terletak di sebelah kanan, sedangkan duplikat di sebelah kiri. Jika leksem dasarnya berakhir dengan fonem konsonan, maka konsonan tersebut dalam duplikatnya dilesapkan.

Contoh (1) Jika leksem dasarnya diakhiri fonem vokal

$\begin{array}{ll}\text { laksem } & \frac{\text { reduplikasi }}{\text { laki-lako 'berjalan' }} \begin{array}{l}\text { 'jalan tak tentu tujuan' } \\ \text { oke 'buang' }\end{array} \text { aki-oke'terbuang-buang' } \\ \text { pote 'pilin' } & \text { pati-pote 'putar balik' }\end{array}$

Contoh (2) Jika leksem dasarnya diakhiri fonem konsonan

leksem

wekok 'menggoyangkan ekor'

wiuk 'memutar'

reduplikasi

waki-wekok 'menggoyang-goyangkan

(ekor atau pantat)'

$\begin{array}{ll}\text { ghedok } & \text { 'goyang pantat' } \\ \text { mbekot } & \text { 'bengkok' } \\ \text { kalek } & \text { 'aduk' } \\ \text { wesak } & \text { 'menebar (biji-bijian)' }\end{array}$

wai-wiuk 'memutar ke kiri dan ke

kanan'

ghadi-ghedok 'menggoyang-goyangkan

pantat'

mbaki-mbekot 'berbengkok-bengkok'

kali-kalek 'mengaduk-aduk'

wasi-wesak 'dibuang-buang

sembarangan'

Contoh (3) Jika bentuk dasar terbentuk dari dua silabi yang fonem vokalnya sama, maka fonem vokal dalam duplikatnya berubah menjadi /i/.

Contoh:

leksem

raka 'ribut'

$\underline{\text { reduplikasi }}$

wongoh 'gigi tonggos'

riki-raka 'ribut gaduh'

wingi-wongoh

'mulut tonggos' 
wangah 'menganga'

wingi-wangah

'mulut menganga'

Yang termasuk dalam tipe ini adalah bentuk yang tidak dikenali leksem dasarnya.

Contoh:

leksem

$\underline{\text { reduplikasi }}$

?

ole-ale

'pendirian tidak tetap, putar balik'

?

ghidi-ghada 'terburu-buru'

bingi-bangah 'idiot'

?

ingi-angah 'bingung'

?

simi-samah 'ekspresi gugup'

?

iki-aka 'panik'

Data di atas menunjukkan bahwa bentuk ale, ghada, bangah, angah, samah, aka tidak pernah berdiri sendiri dalam kalimat. Namun, kuat dugaan bahwa pada masa lampau bentuk-bentuk tersebut merupakan leksem yang dapat berdiri sendiri. Mungkin melalui kajian diakronis dugaan tersebut dapat dibuktikan.

\subsubsection{Makna Gramatikal Reduplikasi}

Makna gramatikal reduplikasi BMDK adalah sebagai berikut.

1) Menyatakan intensif (sungguh-sungguh)

Contoh: mehe-mehe 'keras sekali (pukul)'

$$
\begin{aligned}
& \text { gula-gula 'pagi sekali' } \\
& \text { rope-rapeh 'sangat kotor' } \\
& \text { ghidi-ghada 'sangat terburu-buru' }
\end{aligned}
$$

2) Menyatakan makna iteratif (berkali-kali)

Contoh: laki-lako 'sering jalan" weko-wakok 'menggoyangkan ekor berkali-kali' lelo-lalo 'selalu melihat ke kiri dan ke kanan' wali-walek 'bolak-balik terus'

3) Menyatakan makna kelompok

Contoh: hua-hua 'dua-dua' semongko-semongko 'satu-satu buah' seroto-seroto 'satu-satu keranjang' selo'ang-selo'ang 'satu-satu kamar'

4) Menyatakan makna deintensif (kurang sungguh-sungguh)

Contoh: lako-lako 'sekadar jalan-jalan' lelo-lelo 'sekadar melihat-lihat' tombo-tombo 'bercerita (sekadar menghabiskan waktu)' lonto-lonto 'duduk-duduk (sekadar menghabiskan waktu)'

5) Menyatakan makna jamak

Contoh: mbaru-mbaru watu-watu 'rumah-rumah'

'batu-batu' 


$\begin{array}{ll}\text { kab-kaba } & \text { 'kerbau-kerbau' } \\ \text { lose-lose } & \text { 'tikar-tikar' }\end{array}$

6) Menyatakan makna melebihkan

Contoh: ragi-rigit 'terlalu keriting'

wingi-wongoh 'luar biasa tonggos'

bingi-bangah 'luar biasa bodoh/seperti idiot'

ringi-rangah '(gigi) tumbuh tidak beraturan'

\subsection{Kata majemuk}

Berdasarkan hubungan antarunsur atau antarkonstituen, kata majemuk BMDK dibedakan atas dua jenis, yaitu kata majemuk koordinatif dan kata majemuk subordinatif.

\subsubsection{Kata Majemuk Koordinatif}

Kata majemuk koordinatif adalah kata majemuk yang unsur-unsurnya mempunyai kedudukan yang setara. Unsur-unsurnya tidak dapat dibalikkan, tidak dapat disisipi unsur lain, dan merupakan satu kesatuan yang membentuk makna baru yang bukan makna unsur-unsurnya. Pada umumnya unsur-unsur kata majemuk koordinatif dalam BMDK berkategori nomina: $\mathrm{N}+\mathrm{N}=\mathrm{N}$. Kata majemuk koordinatif dalam BMDK kurang produktif jika dibandingkan dengan kata majemuk subordinatif.

Contoh :

ine ame 'orang tua/ayah ibu'

ibu bapa

ahe kae 'saudara'

adik kakak

mata laho 'matahari'

mata hari

mata wae 'mata air'

mata air

anak rona 'pihak keluarga perempuan(dalam hubungan perkawinan)'

anak suami

anak wina 'pihak keluarga laki-laki (dalam hubungan perkawinan'

anak istri 


hekang gendang 'rumah adat'
rumah gendang
dara weki 'nasib'
darah tubuh

\subsubsection{Kata Majemuk Subordinatif}

Kata majemuk subordinatif adalah kata majemuk yang unsur-unsurnya tidak setara, salah satu unsurnya merupakan inti sedangkan unsur yang lainnya bukan inti atau atribut. Unsur atribut berfungsi sebagai pembatas atau penjelas unsur inti. Berdasarkan kategorinya, kata majemuk subordinatif dalam BMDK terbagi atas tujuh tipe.

1) Tipe I: $N+A d j .=N$

Tipe I ini merupakan gabungan nomina + adjektiva yang menghasilkan kata majemuk berkategori nomina. Unsur inti berkategori nomina, unsur atribut berkategori adjektiva. Unsur atribut berfungsi menjelaskan keadaan, sifat, dan ciri unsur inti.

Contoh:

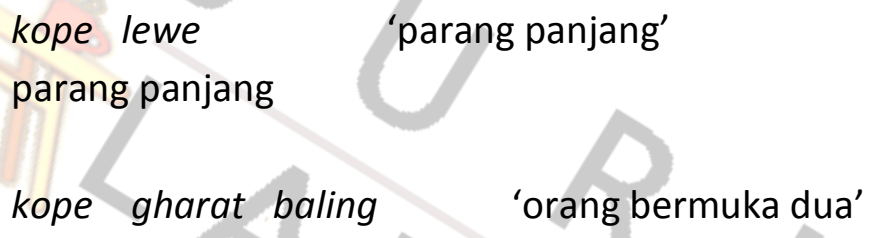


2) Tipe II: $N+N=N$

Tipe II ini merupakan hasil gabungan nomina + nomina menghasilkan kata majemuk berkategori nomina. Unsur inti bakategori nomina, unsur atribut bekategori nomina pula. Unsur atribut berfungsi menyatakan posesif atau milik, bahan (terbuat dari).

Contoh: bako kope 'sarung parang' sarung parang

rapa jarang 'tali kekang kuda'

tali kekang kuda

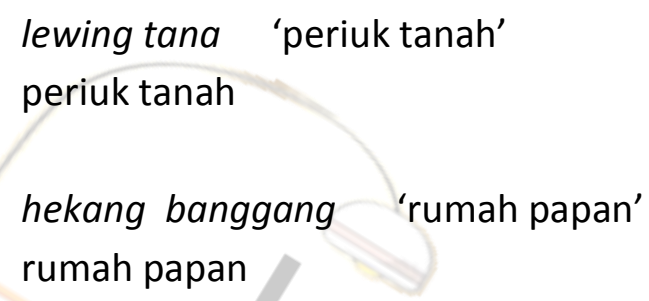

3) Tipe III $: \mathrm{V}+\mathrm{N}=\mathrm{V}$

Tipe III ini berunsur inti verba plus unsur atribut nomina menghasilkan kata majemuk berkategori verba. Unsur atribut befungsi menjelaskan bahwa tindakan itu dilakukan dengan menggunakan dan atau meniru tindakan benda yang dinyatakan dalam unsur atribut tersebut.

Contoh:

lonto asu 'duduk termenung'

duduk anjing

lako wai 'jalan kaki'

jalan kaki

wiku wai 'duduk bersila'

bersila kaki 
sebong jarang 'mandi sebagian badan (kepala tidak direndam)' mandi kuda

nanging pake 'berenang dengan kepada di dalam air' berenang kodok

lempo pake 'meloncat dengan tumpuan kaki dan tangan' loncat kodok

tepeng but 'bersembunyi (badan masih kelihatan)' sembunyi puyuh

4) Tipe IV: $\mathrm{N}+\mathrm{V}=\mathrm{N}$

Tipe IV ini berunsur inti nomina plus unsur atribut verba menghasilkan kata majemuk berkategori nomina. Atribut merupakan pembatas tindakan yang unsur inti.

\section{Contoh:}

ghae lako 'teman seperjalanan' teman jalan

ghae labar 'teman bermain' teman main

ata tako 'pencuri'

orang curi

halang lako 'tempat lewat'

jalan jalan

jarang rie 'kuda pacu'

kuda pacu

kaba tekek 'kerbau pengangkut beban'

kerbau pikul

asu lo'eng 'anjing pemburu'

anjing gonggong 
5) Tipe $V: V+A d j .=V$

Tipe $V$ ini berunsur inti verba plus unsur atribut adjektiva menghasilkan kata majemuk berkategori verba. Unsur atribut menyatakan intensitas, kualitas, dan atau cara tindakan itu dilakukan.

Contoh:

$$
\begin{aligned}
& \text { lako lelang 'jalan cepat' } \\
& \text { jalan cepat } \\
& \text { lonto leok 'duduk bersama' } \\
& \text { duduk melingkar }
\end{aligned}
$$$$
\text { lonto torok 'duduk berbaris' }
$$$$
\text { duduk berbaris }
$$$$
\text { retang mbare 'menangis sekuat-kuatnya' }
$$$$
\text { menangis besar }
$$

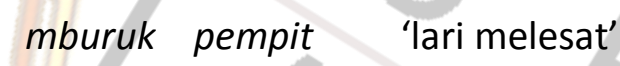

lari kecepatan tinggi

luhi pidot 'lari terbirit-birit'

lari takut

toko lemot 'tidur nyenyak'

tidur nyenyak

pika pa'u 'banting harga'

jual jatuh

6) Tipe $\mathrm{VI}: \mathrm{Adj}+\mathrm{N}=$ Adj.

Tipe $\mathrm{VI}$ ini berunsur inti adjektiva plus unsur atribut nomina menghasilkan kata majemuk berkategori adjektiva. Unsur atribut menyatakan ciri unsur inti sama atau mirip dengan benda yang dinyatakan dalam unsur atribut.

Contoh:

mansak tekur 'kuning langsat (warna kulit perempuan)'

putih tekukur 


\section{melong pau 'hitam manis' \\ ? mangga}

mame wulang 'setengah matang (jagung goreng )'

masak bulan

Selain menyatakan hubungan keserupaan, atribut dalam kata majemuk tipe VI ini juga merupakan pembatas keadaan yang dinyatakan dalam unsur inti.

Contoh:

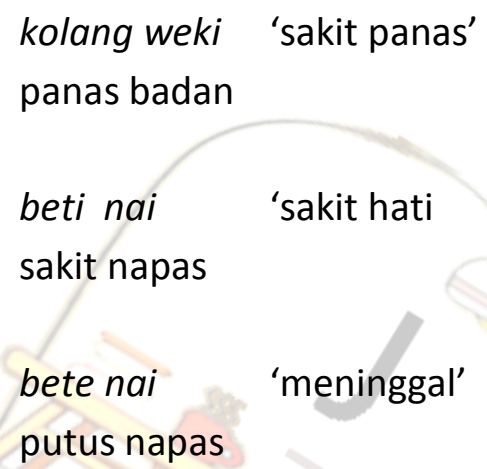

Baik unsur inti maupun atribut dalam tipe VII ini berkategori adjektiva. Unsur atributnya merupakan morfem unik yang tidak memiliki makna leksikal. Morfem tersebut muncul secara kolokatif atau hanya berpasangan dengan leksem tertentu. Bentuk ini sama dengan bentuk kata majemuk bahasa Indonesia: gelap gulita, hitam legam. Morfem gulita, legam tidak memiliki makna leksikal dan selalu berpasangan tetap dengan leksem tertentu. Kata majemuk tipe VII ini berkategori adjektiva. Unsur atribut menerangkan kualitas atau kadar unsur inti.

Contoh:

wau woeh 'bau amis'

bau ?

wau nembur bau busuk'

bau ?

dereng weret 'merah menyala'

merah ?

bakok nggera 'putih sekali (bule)'

putih ? 


\section{miteng kirek 'hitam legam' \\ hitam ?}

8) Tipe VIII: $\mathrm{N}+\mathrm{Num} .=\mathrm{N}$

Tipe VIII ini merupakan perpaduan unsur inti nomina dan unsur atribut numeralia yang menghasilkan kata mejemuk nomina. Unsur atribut menerangkan keberadaan unsur inti.

Contoh:

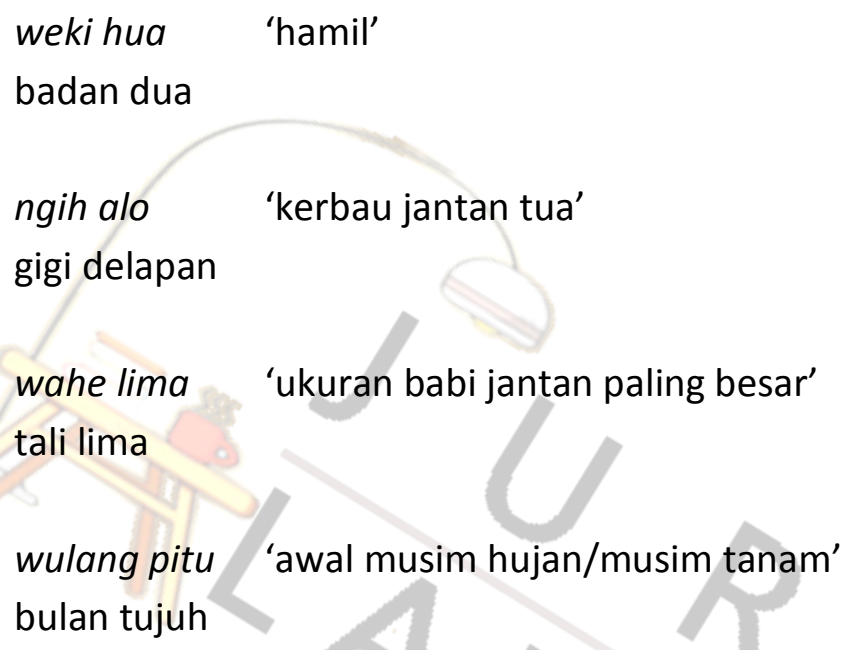

\subsubsection{Kata Majemuk Idiomatis}

Idiom adalah konstruksi yang maknanya tidak sama dengan makna komponenkomponennya (Kridalaksana, 1992:107). Jadi, kata majemuk idiomatis adalah kata majemuk yang maknanya tidak tidak sama dengan makna unsur-unsur-nya. Kata majemuk idiomatis dalam BMDK pada umumnya unsur-unsurnya terdiri atas tiga leksem. Bedasarkan hubungan antarunsurnya, kata majemuk idiomatis BMDK termasuk kata majemuk subordinatif. Secara semantis, pada umumnya kata majemuk idiomatis BMDK bermakna konotasi negatif karena merupakan sindiran bagi orang-orang yang berperilaku negatif.

Contoh :

kope gharat baling 'orang bermuka dua'

parang tajam kedua sisinya

ipung sa tiwu 'orang yang berpandangan sama (berkonotasi negatif)'

ikan satu kolam

wae tiku tedeng 'hubungan kekeluargaan yang langgeng'

air timba terus menerus 
poti woleng pong 'lain orang lain adatnya'

hantu beda tempat tinggal

la'it ipo ru 'melanggar prinsip sendiri'

jilat ludah sendiri

tombo siku ru 'menceritakan kejelekan keluarga sendiri'

cerita siku sendiri

roba pete bea ' dapat jodoh berhidung pesek'

jatuh di tempat rata

Kontruksi di bawah ini dapat pula dimasukkan dalam kelompok kata majemuk idiomatis karena baik secara struktural maupun secara semantis memenuhi kriteria kata majemuk. Secara struktural, konstruksi di bawah ini bentuknya tetap dan tidak dapat disisipi unsur lain, unsur-unsurnya tidak dapat diperluas dan atau dibalikkan susunannya. Secara semantis, konstruksi tersebut mengandung satu kesatuan makna atau mengacu pada satu referen tertentu.

Contoh:

paang olo ngaung muhi

'seisi kampung'

dari depan sampai belakang

wan koe etan tua 'semua orang tidak terkecuali'

dari kecil hingga tua

ulun le wain lau 'seluruh daerah'

di hulu dan di hilir

parn awo kelepn hale 'seluruh jagat raya'

terbit di timur terbenam di barat

padir wa'i rintuk ha'i

'bermusyawarah'

baris kaki kumpul kepala

Konstruksi di atas biasanya terdapat dalam ungkapan-ungkapan khusus seperti bahasa ritual, jarang digunakan dalam tuturan biasa atau percakapan sehari-hari. 


\section{Simpulan dan Saran}

\subsection{Simpulan}

Hasil penelitian dapat disimpulkan sebagai berikut.

1) Reduplikasi

Reduplikasi BMDK dibedakan atas dua tipe utama, yaitu: (1) tipe I adalah reduplikasi tanpa perubahan fonem dan (2) dan tipe II adalah reduplikasi dengan perubahan fonem.

Tipe I memiliki tiga varian.

Varian I: jika in masukannya berupa leksem yang berakhir dengan fonem vokal maka luarannya (reduplikasi) tidak mengalami perubahan bentuk

Varian II: jika masukannya berupa leksem yang berakhir dengan fonem konsonan maka konsonan akhir pada konstituen reduplikasi sebelah kanan cenderung mengalami pelesapan.

Varian III: jika masukannya terdiri atas tiga silabi walaupun diakhiri konan, konsonan tersebut tidak mengalami pelesapan atau tidak mengalami perubahan bentuk.

Tipe II memiliki dua varian.

Varian I: semua fonem vokal pada silabi pertama dalam bentuk dasar berubah menjadi /a/ dalam duplikatnya. Bentuk dasar di sebelah kiri, duplikat di sebelah kanan. Jika leksem dasarnya berakhir dengan fonem konsonan, maka fonem tersebut dilesapkan. Pelesapan terjadi pada bentuk dasar, bukan pada duplikat.

Varian II: Semua fonem vokal, baik vokal pada suku pertama maupun pada suku kedua berubah menjadi /a/ dan /i/ dalam duplikatnya. Bentuk dasar terletak di sebelah kanan, sedangkan duplikat di sebelah kiri. Jika leksem dasarnya berakhir dengan fonem konsonan, maka konsonan tersebut dalam duplikatnya dilesapkan.

Makna grmatikal reduplikasi BMDK adalah sebagai berikut.

(1) Menyatakan intensif (sungguh-sungguh)

(2) Menyatakan makna iteratif (berkali-kali)

(3) Menyatakan makna kelompok

(4) Menyatakan makna deintensif (kurang sungguh-sungguh)

(5) Menyatakan makna jamak

(6) Menyatakan makna melebihkan

2) Kata majemuk/pemajemukan

Berdasarkan hubungan antarkonstituen, kata majemuk BMDK terdiri atas dua jenis, yaitu kata majemuk koordinatif dan kata majemuk subordinatif.

Kata majemuk koordinatif dalam BMDK kurang produktif jika dibandingkan dengan kata majemuk subordinatif. Kata majemuk koordinatif hanya ditemukan satu tipe yakni berkategori nomina dan konstituennya terdiri atas nomina $(\mathrm{N}+\mathrm{N}=\mathrm{N})$. Kata majemuk subordinatif ditemukan tujuh tipe. Ketujuh tipe tersebut sebagai berikut. 
Tipe I: $\mathrm{N}+\mathrm{Aj} .=\mathrm{N}$

Unsur atribut menjelaskan keadaan, sifat, dan ciri unsur inti.

(1) Tipe II: $N+N=N$.

Unsur atribut menyatakan posesif atau milik, bahan (terbuat dari).

(2) Tipe III: $V+N=V$

Unsur atribut menyatakan bahwa tindakan tersebut dilakukan dengan menggunakan atau meniru tindakan benda yang dinyatakan dalam unsur atribut tersebut.

(3) Tipe IV: N + V = N.

Atribut merupakan pembatas tindakan yang dinyatakan dalam unsur inti.

(4) Tipe $V: V+A j=V$

Atribut menyatakan intensitas, kualitas, dan atau cara tindakan itu dilakukan.

(5) Tipe VI: $A j+N=A j$.

Atribut menyatakan ciri unsur inti sama atau mirip dengan benda yang dinyatakan dalam unsur atribut.

(6) Tipe VII: $A j+A j=A j$.

Atribut menerangkan kualitas atau kadar unsur inti.

(7) Tipe VIII: N + Num.

Atribut menerangkan keberadaan unsur inti.

\subsection{Saran}

Ada yang unik dan sangat menarik dari bahasa ini, yaitu reduplikasi. Bahasa ini kaya akan ungkapan emosional yang diekspresikan dengan bentuk reduplikasi. Fenomena tersebut belum dapat diungkap dalam penelitian ini. Penelitian deskriptif seperti ini memiliki keterbatasan dalam mengkaji dan mengungkapkan fenomena bahasa yang demikian. Oleh sebab itu perlu penelitian lebih lanjut dengan pendekatan lain seperti kajian sosiolinguistik.

\section{DAFTAR PUSTAKA}

Adnyana, Ida Bagus Artha. "Reduplikasi Morfemis Bahasa Bali Modern" Dalam LINGUISTIKA. Edisi Perdana, 1994. Hal. 22-23

Ahmadi, Nur. "Reduplikasi dalam Bahasa Sasak: Alternatif Pendekatan Segmental." Dalam LINGUISTIKA: Tahun IV, Edisi 6 Maret 1997. Hal. 58-68.

Antonius, Porat, dkk. 2000. "Proses Morfologis Bahasa Rembong Kecamatan Elar Kabupaten Manggarai.’Laporan Penelitian. Kupang: FKIP Undana.

Aronoff, Mark. 1981. Word Formation in Generatif Grammar. Cambridge: MIT Press. 
Bustan, F. 1997. "Reduplikasi Bahasa Manggarai Dialek Manggarai Tengah”. Laporan Penelitian: Kupang: FKIP.

Bybee, Joan L. 1985. Morphology: A Study of Relation Between Meaning and Form. Amsterdam: John Benyamins publishing Company.

Durie, Mark. 1985. A Grammar of Acehness on The Basis of north Aceh. New York: Foris Publication.

Elson, Benyamin \& Velma B. Pickett 1993. Beginning Morphology and Syntax. Summer Institute of Linguistics.

Gande, Vinsensius. 2001. "Reduplikasi Morfemis Bahasa Manggarai Subdialek Kempo". Skripsi Sarjana. Kupang: FKIP Undana.

Jehane, Hendrikus. 2001. "Klitikisasi Bahasa Rembong di Kecamatan Elar Kabupaten Manggarai.” Dalam GURU BAHASA, Tahun VI, No, 10, Januari-Juni 2001.

Katamba, Francis. 1993. Morphology. London: Macmillan Press Ltd.

Kosmas, J. 1997. "Kata Tugas Bahasa Manggarai Dialek Regho”. Dalam GURU BAHASA. Tahun II, No 4, Januari 1997. Hal.33-44.

Kridalaksan, Harimurti. 1995. "Teori Linguistik di Indonesia dalam Beberapa Dasawarsa Terakhir Ini.” Dalam Majalah Universitas Katolik Indonesia Atmajaya. Tahun VIII, No,I April 1995. Hal. 1-18.

Kridalaksana, Harimurti. 1986. Pembentukan Kata dalam Bahasa Indonesia. Jakarta: Gramedia.

Kridalaksana, Harimurti. 1988. Beberapa Prinsip Perpaduan Leksem dalam Bahasa Indonesia. Jogyakarta: Kanisius.

Kridalaksana, Harimurti. 1992. Pembentukan Kata dalam Bahasa Indonesia. Jakarta: Gramedia.

Lieber, Rochelle. 1992. Decontructing Morphology: Word Formation in Sintactic Theory. Chicago: The University Press of Chicago.

McCarty, Andrew. 1992. Current Morphology. London: Rodledge.

Moeliono, Anton. Ed. 1988. Tata Bahasa Baku Bahasa Indonesia. Jakarta: Balai Pustaka.

Parera, Jos Daniel. 1994. Morfologi Bahasa. Jakarta: Gramedia pustaka Utama.

Ramlan, M. 1983. Morfologi: Suatu Tinjauan Deskriptif. Yogyakarta: CV Karyono.

Scalises, Sergio. 1984. Generative Morphology. New York. Forris Publication.

Semiun, A. 1996. "Nominalisasi dalam Bahasa Manggarai. Laporan Penelitian”. Kupang: Fkip Undana. 
Semiun, A. dkk. 1998. "Klitika Bahasa Manggarai Dialek Manggarai Tengah Nusa Tenggara Timur.” Laporan Penelitian. Kupang: FKIP.

Spencer, Andrew. 1993. Morphological Theory. Cambridge: Blackwell.

Tama, I Wayan. 1994. "Pengafiksan Bahasa Kolo". Dalam LINGUISTIKA. Edidi Perdana 1994, Hal. 13-21.

Troeboes, dkk. 1985. "Struktur Bahasa Manggarai." Laporan Penelitian. Kupang: FKIP Undana

Verhaar, J.W.M 1996. Azas-azas Linguistik. Yogyakarta: Gadjah Mada University Press.

Verhaar, J.W.M. 1984. “Affixation in Contemporary Indonesian.” Dalam NUSA: Linguistics Studies of Indonesian and Other Language in Indonesia. Vol. 18, 1984. Hal. 27-62.

Verheijen, J.A. 1991. Manggarai dan Wujud Tertinggi. Jakarta. PDII-LIPI. 